\title{
PENYERTAAN PADA TINDAK PIDANA KORUPSI DANA BANTUAN SOSAL
}

\author{
Nuredah \\ Fakultas Hukum Universitas Hasanuddin, Makassar, \\ Email : nuredah97@gmail.com \\ Haeranah \\ Fakultas Hukum Universitas Hasanuddin, Makassar, \\ Email : haeranahnurdin1966@gmail.com
}

\begin{abstract}
Abstrak
Penelitian ini bertujuan Untuk menganalisis pertanggungjawaban pidana pelaku turut serta dalam tindak pidana korupsi penyalahgunaan kewenangan yang merugikan keuangan Negara dan pemberian memo untuk pencairan Dana Bansos dapat dikualifikasikan sebagai turut serta dalam tindak pidana korupsi penyalahgunaan kewenangan yang merugikan keuangan negara. Penelitian ini menggunakan metode penelitian hukum normatif. Adapun hasil dari penelitian ini yaitu pertanggungjawaban pelaku tindak pidana korupsi secara utuh telah diatur melalui UU PTPK; Apabila Memo yang dikeluarkan oleh Drs. Benny Alexander Litelnoni, SH. M.Si. selaku wakil Bupati dan Memo tersebut dipedomani oleh bawahannya yang mengakbatkan kerugian negara dan memenuhi unsur-unsur Pasal 2 dan Pasal 3 maka Memo tersebut dapat dikualifikasikan sebagai bentuk turut serta.
\end{abstract}

Kata Kunci: Pertanggungjawaban Pidana, Tindak Pidana Korupsi, Memo

\section{Abstract}

This study aims to analyze the criminal responsibility of the perpetrators who participate in the criminal act of corruption, abuse of authority that is detrimental to State finances and the provision of memos for disbursement of Social Assistance Funds can qualify as participating in criminal acts of corruption, abuse of authority that harms state finances. This research uses normative legal research methods. The results of this research are that the full accountability of the perpetrators of corruption has been regulated through the PTPK Law; If the memo issued by Drs. Benny Alexander Litelnoni, SH. M.Si. as the representative of the Regent and the Memo is guided by his subordinates which results in state losses and fulfills the elements of Article 2 and Article 3, the Memo can qualify as a form of participation.

Keyword: Criminal Accountability, Corruption Crime, Memo 


\section{PENDAHULUAN}

Pada hakikatnya, korupsi dapat merusak stuktur pemerintahan, dan menjadi penghambat utama terhadap jalannya pemerintahan dan pembangunan pada umumnya. Salah satu penyebab tidak optimalnya pembangunan adalah praktik korupsi, karena korupsi berpengaruh terhadap iklim ivestasi, pertumbuhan ekonomi dan peningkatan pendapan masyarakat. ${ }^{1}$

Korupsi merupakan produk dari sikap hidup satu kelompok masyarakat yang memakai uang sebagai standard kebenaran dan sebagai kekuasaan mutlak, akibatnya kaum koruptor yang yang kaya raya dan para politisi korup yang berlebihan uang bisa masuk ke dalam golongan elite yang berkuasa dan sangat dihormati, mereka ini juga akan menduduki status sosial yang tinggi dimata masyarakat. ${ }^{2}$

Berbicara mengenai perkembangan pemberantasan korupsi, saat ini hal itu semakin menunjukkan titik terang sebagai upaya pemerintah dalam menanggapi tindak pidana korupsi di Indonesia. Pemberantasan korupsi secara hukum adalah dengan mengandalkan diperlakukannya secara konsisten Undang-Undang tentang Pemberantasan Tindak Pidana Korupsi dan berbagai ketentuan terkait yang bersifat represif. Undang-Undang yang dimaksud adalah Undang-Undang No 31 Tahun 1999 tentang Pemberantasan Tindak Pidana Korupsi, sebagaimana diubah menjadi Undang-Undang Nomor 20 Tahun 2001. Bila kita cermati dari awal sampai akhir tujuan khusus yang hendak dicapai adalah bersifat umum, yaitu penegakan keadilan hukum secara tegas bagi siapa saja yang terbukti melakukan tindak pidana korupsi.

Menurut Undang-Undang Nomor 31 Tahun 1999 Pasal 2 ayat (1) Undang-Undang Tipikor menyebutkan setiap orang yang melawan hukum melakukan perbuatan memperkaya diri sendiri atau orang lain dan suatu korporasi yang dapat merugikan keuangan negara atau perekonomian negara dipidana dengan pidana penjara minimal 4 tahun dan maksimal 20 tahun dan denda paling sedikit 200 juta rupiah dan paling banyak 1 miliar rupiah. Dan dalam Pasal 3 disebutkan bahwa, Setiap orang yang dengan tujuan menguntungkan diri sendiri atau orang lain atau suatu korporasi, menyalahgunakan kewenangan, kesempatan atau sarana yang ada padanya karena jabatan atau kedudukan yang dapat merugikan keuangan negara atau perekonomian negara, dipidana dengan pidana penjara seumur hidup atau pidana penjara paling singkat 1 (satu) tahun dan paling lama 20

${ }^{1}$ Fahmi Idris, Selamatkan Uang Negara, dengan Tata Kelola Keuangan Negara yang Benar, Expese, Jakarta, 2012, hlm. 2

2 Erika Revida, Korupsi di Indonesia: Masalah dan Solusinya, http://repositry.usu.ac.diakses tanggal 14 April 2012, 18:18 PM. 
(dua puluh) tahun dan atau denda paling sedikit Rp. 50.000.000,00 (lima puluh juta rupiah) dan paling banyak Rp. 1.000.000.000,00 (satu miliar rupiah). Dapat kita lihat unsur-unsur yang memenuhi Tindak Pidana Korupsi yang terdapat didalam Undang-Undang Nomor 31 Tahun 1999 Pasal 3 yaitu sebagai berikut:

a. Setiap orang;

b. Dengan tujuan menguntungkan diri sendiri atau orang lain atau suatu korporasi;

c. Menyalahgunakan kewenangan, kesempatan atau sarana

d. Yang ada padanya karena jabatan atau kedudukan;

e. Dapat merugikan keuangan Negara atau perekonomian Negara.

Ketentuan-ketentuan mengenai Pemidanaan Korupsi yang ada menurut Undang-Undang No. 31 Tahun 1999 sebagaimana telah dirubah menjadi Undang-Undang No. 20 Tahun 2001 tentang Pemberantasan Tindak Pidana Korupsi telah disesuaikan dengan Undang-Undang sebelumnya. Dalam Undang-Undang ini ditemukan adanya ancaman pidana minimum khusus, pidana denda yang lebih tinggi dan ancaman pidana mati yang merupakan pemberatan pidana.

Sanksi minimum khusus ini agar pelaku tindak pidana korupsi tidak dapat lolos dari ancaman pidana yang menjeratnya.

Tindak pidana korupsi menimbulkan kerugian negara yang meluas. Tindak pidana ini merupakan tindak pidana yang dalam pelaksanaannya selalu dilakukan secara bersama-sama. Bentuk campur tangan beberapa orang secara bersama- sama ini termasuk kedalam ajaran penyertaan dalam hukum pidana. $^{3}$ Ajaran penyertaan terbagi menjadi dua, yaitu meliputi pelaku peserta dan pelaku yang melakukan pembantuan dalam tindak pidana. Dalam konteks penyertaan dan pembantuan, memiliki tujuan yang memperluas norma serta kaidah yang terkandung dalam tindak pidana, baik subjek maupun perbuatan. Pada KUHP, penyertaan dan pembantuan telah diatur pada Pasal 55 dan Pasal 56. Bentuk-bentuk yang dimaksud pada pasal tersebut, yaitu :
a. Melakukan (pleger);
b. Menyuruh Melakukan (doen pleger);
c. Turut Melakukan (medepleger);
d. Pembujukan (uitlokker);
e. Membantu Melakukan (medeplichtige). ${ }^{4}$

${ }^{3}$ Mia Amiati, Perluasan Penyertaan dalam Tindak Pidana Korupsi Menurut UNCATOC 2000 dan UNCAC 2003, Referensi, 2013, hlm 108.

${ }^{4}$ Ibid, hlm 110. 
Dalam beberapa tahun belakangan ini, mungkin kata Dana Bantuan Sosial kemudian disingkat Dana Bansos sering terdengar baik melalui media maupun berita di berbagai tempat. Bantuan sosial tersebut menjadi salah satu jenis belanja daerah yang menyedot perhatian banyak, bukan saja masyarakat atau kelompok masyarakat tetapi juga pemerintahan, anggota dewan perwakilan rakyat daerah, bupati, gubernur, walikota yang berkepentingan dengan Bansos, dengan demikian rekening bansos memiliki resiko cukup tinggi untuk disalahgunakan atau diselewengkan.

Perihal dana bansos, dalam pasal 1 angka 15 Peraturan Menteri Dalam Negeri kemudian disingkat Permendagri Nomor 32 Tahun 2011 tentang dana Bansos dan Hibah disebutkan bahwa yang dimaksud Dana Bansos adalah "pemberian bantuan berupa uang/barang dari pemerintah daerah kepada individu, keluarga, kelompok, dan/atau masyarakat yang sifatnya tidak secara terus-menerus dan selektif yang bertujuan untuk melindungi dari kemungkinan terjadinya resiko sosial". ${ }^{5}$

Dalam prakteknya selama ini, dana bansos ini sering menimbulkan berbagai masalah khususnya yang bersumber dari Anggaran Pendapatan dan Belanja Daerah (APBD) baik saat penganggarannya maupun pengelolaannya atau pencairannya. Banyak terjadi penyelewengan dana bantuan sosial untuk kepentingan diri sendiri.

Kasus semisal hal tersebut, sebagaimana juga terjadi dalam Studi Putusan Nomor 2811 K/Pid.Sus/2015, yakni kasus penyertaan dalam tindak pidana korupsi dana bansos. Pada putusannya, hakim menjatuhkan putusan terdakwa secara sah dan meyakinkan bersalah melakukan tindak pidana korupsi secara bersama-sama. Namun timbul permasalahan lain dalam kasus ini, pelakunya berjumlah tiga orang, yang di jatuhi putusan pengadilan hanya dua orang atau yang di suruh melakukan, sedangkan yang menyuruh melakukan dalam hal ini adalah Drs. Beny Litelnony selaku Wakil Bupati Timur Tengah Selatan (Pembuat Memo Pencairan Dana Bansos) kasusnya belum diproses oleh pihak kejaksaan.

Berdasarkan hal tersebut, maka terdapat permasalahan yang hendak dipecahkan melalui penelitian ini, yaitu terkait bagaimanakah pertanggungjawaban pidana pelaku turut serta dalam tindak pidana korupsi penyalahgunaan kewenangan yang merugikan keuangan negara? Dan apakah pemberian Memo untuk pencairan Dana Bansos dapat dikualifikasikan sebagai turut serta dalam tindak pidana korupsi penyalahgunaan kewenangan yang merugikan keuangan negara?

\footnotetext{
${ }^{5}$ Peraturan Menteri Dalam Negeri Nomor 32 Tahun 2011 sebagaimana telah dibah dengan Peraturan Menteri Dalam Negeri Nomor 39 Tahun 2012 tentang Pedoman Pemberian Hibah dan Bantuan yang bersumber dari APBD, Pasal 1 angka 15.
} 


\section{METODE PENELITIAN}

Penelitian yang akan Penulis lakukan adalah penelitian hukum normatif. Dalam penelitian hukum ini, penulis menggunakan penelitian hukum yang bersifat deskriptif. Dalam penelitian normatif terdiri dari 5 penekatan yakni pendekatan perundang-undangan, pendekatan konseptual, pendekatan historis, pendekatan kasus dan pendekatan perabndingan. Dalam penelitian ini hanya menggunakan dua pendekatan yakni pendekatan perundang-undangan dan pendekatan kasus.

Berdasarkan jenis penelitian yang digunakan yaitu penelitian hukum normatif yang menggunakan jenis data sekunder berupa bahan hukum primer, sekunder dan tersier.

1. Bahan hukum primer adalah bahan hukum mengikat yang terdiri dari norma atau kaidah dasar yakni Undang-Undang Dasar Negara Republik Indonesia Tahun 1945, Undang-Undang terkait, dan Yurisprudensi.

2. Bahan hukum sekunder, yaitu bahan yang memberikan penjelasan mengenai bahan hukum primer seperti naskah akademik rancangan undang-undang, hasil penelitian, dan pendapat pakar hukum.

3. Bahan hukum tersier, yaitu bahan yang memberikan petunjuk maupun penjelasan terhadap bahan hukum primer dan bahan hukum sekunder, seperti kamus hukum dan ensiklopedia. ${ }^{6}$

Teknik pengumpulan bahan hukum yang digunakan oleh penulis adalah Penelitian normatif. Dalam melakukan penelitian normatif penulis melakukan pengkajian dan mengolah bahan hukum tersebut dalam dokumen-dokumen resmi, peraturan perundang-undangan, jurnal dan kajian-kajian ilmiah serta buku-buku yang berhubungan dengan permasalahan termasuk mengumpulkan bahan hukum melalui media elektronik dan media-media informasi lainnya.

Hasil yang diperoleh secara langsung disusun secara sistematis dan analisis sesuai pendekatan normatif, maka pendekatan yang digunakan adalah analisis secara deskriptif kualitatif yaitu bahan hukum yang bertitik tolak pada upaya dalam menemukan asas dan teori dalam menganalisis dalam penelitian ini. Hal ini dimaksudkan agar dapat menggambarkan keseluruhan hasil data yang diperoleh. Selain itu penulis berharap dapat menggambarkan pendapat para ahli atau pakar hukum, maupun referensireferensi yang telah dikumpulkan. Dari semua hasil-hasil yang diperoleh penulis diharapkan dapat dianalisis yang nantinya akan dihubungkan

6 Amiruddin dan zainal asikin, Pengantar Metode Penelitian Hukum, Jakarta: Rajawali Pers, 2014, hlm. 118-119. 
dengan rumusan peraturan perundang-undangan yang terkait dan dapat diambil kesimpulan atau jawaban guna menjawab permasalahan yang diteliti.

\section{PEMBAHASAN}

1. Pertanggungjawaban Pidana Pelaku Turut Serta Pada Tindak Pidana Korupsi Penyalahgunaan Kewenangan yang Merugikan Keuangan Negara

Putusan Mahkamah Konstitusi No. 003/PUU-IV/2006 terhadap sistem pembuktian tindak pidana korupsi, menyatakan dalam pengertian bahwa melawan hukum materil telah dinyatakan tidak mempunyai kekuatan hukum mengikat, sehingga yang dimaksud dalam Pasal 2 ayat (1) UndangUndang No. 31 Tahun 1999 Jo Undang-Undang No.20 Tahun 2001 tentang Pemberantasan Tindak Pidana Korupsi ini hanya perbuatan melawan hukum formil saja. Adapun Amar Putusan MK pada pokoknya berbunyi sebagai berikut :

"menyatakan penjelasan Pasal 2 ayat (1) Undang-Undang Republik Indonesia Nomor 31 Tahun 1999 tentang Pemberantasan Tindak Pidana Korupsi sebagaimana telah diubah dengan Undang-Undang Nomor 20 Tahun 2001 tentang perubahan atas Undang-Undang Republik Indonesia Nomor 31 Tahun 1999 tentang Pemberantasan Tindak Pidana Korupsi (Lembaran Negara Republik Indonesia Nomor 134, Tambahan lembaran Negara Republik Indonesia Nomor 4150) sepanjang frasa yang berbunyi, "Yang dimaksud dengan 'secara melawan hukum dalam arti formil maupun dalam arti materiil, yakni meskipun perbuatan tersebut tidak diatur dalam peraturan perundang-undangan, namun apabila perbuatan tersebut dianggap tercela karena tidak sesuai dengan rasa keadilan atau norma-norma kehidupan sosial dalam masyarakat, maka perbuatan tersebut dapat dipidana" 7

Untuk dapat dipidananya si pelaku, diharuskan tindak pidana yang dilakukannya itu memenuhi unsur-unsur delik yang telah ditentukan dalam undang-undang. Dilihat dari sudut terjadinya tindakan yang dilarang, seseorang akan dipertanggungjawabkan atas tindakan-tindakan tersebut, apabila tindakan tersebut melawan hukum serta tidak ada alasan pembenar atau peniadaan sifat melawan hukum untuk pidana yang dilakukannya. Dan dilihat dari sudut kemampuan bertanggung jawab maka hanya seseorang

${ }^{7}$ Putusan Mahkamah Konstitusi No. 003/PUU-IV/2006 
yang mampu bertanggung jawab yang dapat di pertanggungjawabkan atas perbuatannya. ${ }^{8}$

Ditambahkan pula, bahwa tiadanya alasan pemaaf merupakan pula bagian ke empat dari kesalahan. Oleh karena dalam tulisan ini dipisahkan antara perbuatan dan rumusan delik di satu pihak sebagai actus reus dan kesalahan dipihak lain sebagai mens rea sebagaimana dilakukan oleh Moeljatno, Roeslan Saleh, dan A Z Abidin, maka bagian subjektif ini ditempatkan khusus dalam BAB V. ${ }^{9}$ Bagaimana dengan pertanggungjawaban korporasi dalam tindak pidana korupsi dapat dibaca pada Pasal 20 UU TPK yang dirumuskan sebagai berikut:

1. Dalam hal tindak pidana korupsi dilakukan oleh atau atas nama suatu korporasi, maka tuntutan dan penjatuhan pidana dapat dilakukan terhadap korporasi dan atau pengurusnya.

2. Tindak pidana korupsi dilakukan oleh korporasi apabila tindak pidana tersebut dilakukan oleh orang-orang baik berdasarkan hubungan kerja maupun berdasarkan hubungan lain, bertindak dalam lingkungan korporasi tersebut baik sendiri maupun bersama-sama.

3. Dalam hal tuntutan pidana dilakukan terhadap suatu korporasi, maka korporasi tersebut diwaliki oleh pengurus.

4. Pengurus yang mewakili korporasi sebagaimana dimaksud dalam ayat (3) dapat diwakili oleh orang lain.

5. Hakim dapat memerintahkan supaya pengurus korporasi menghadap sendiri di pengadilan dan dapat pula memerintahkan supaya pengurus terebut dibawa ke sidang pengadilan.

6. Dalam hal tuntutan pidana dilakukan terhadap korporasi, maka panggilan untuk menghadap dan menyerahkan surat panggilan tersebut disampaikan kepada pengurus ditempat tinggal pengurus atau tempat pengurus berkantor.

7. Pidana pokok yang dapat dijatuhkan terhadap korporasi hanya pidana denda dengan ketentuan maksimum pidana ditambah $1 / 3$ (satu per tiga). ${ }^{10}$

8 Amir Ilyas. Asas-Asas Hukum Pidana, Rangkang Education Yogyakarta \& PuKAP-Indonesia. Yogyakarta. 2012. hlm. 73

${ }^{9}$ Andi Hamzah, Asas-Asas Hukum Pidana Edisi Revisi, Jakarta, Rineka Cipta, 2014, hlm. 111.

10 Adami Chazawi, 2016. Hukum Pidana Korupsi di Indonesia (Edisi Revisi). Jakarta: PT Raja Grafindo Persada. hlm. 320-321 
Dalam Undang-Undang No. 31 Tahun 1999 tentang Pemberantasan Tindak Pidana Korupsi sebagaimana diubah menjadi Undang-Undang Nomor 20 Tahun 2001 diatur dalam Pasal 3 yang berbunyi:

"Setiap orang yang dengan tujuan menguntungkan diri sendiri atau orang lain atau suatu korporasi, menyalahgunakan kewenangan, kesempatan atau sarana yang ada padanya kerana jabatan atau kedudukan yang dapat merugikan keuangan negara atau perekonomian negara, dipidana dengan pidana penjara seumur hidup atau pidana penjara paling singkat 1 (satu) tahun dan paing lama 20 (dua puluh) tahun dan denda paling sedikit Rp. 50.000.000,00 (lima puluh juta rupiah) dan paling banyak Rp. 1.000.000.000,00 (satu miliar rupiah).”

2. Pemberian Memo Untuk Pencairan Dana Bansos Dapat Dikualifikasikan Sebagai Turut Serta Pada Tindak Pidana Korupsi Penyalahgunaan Kewenangan yang Merugikan Keuangan Negara (Studi Putusan Mahkamah Agung Nomor 2811/Pid.Sus/2015)

"MEMO" tidak dapat dikualifikasikan sebagai turut serta dalam suatu tindak pidana korupsi. Seperti yang kita ketahui bahwa memo (catatan) yang diberikan oleh orang lain bukanlah suatu keharusan atau perintah yang harus kita laksanan. Memo hanya berupa catatan yang bisa kita laksanakan dan bisa tidak kita laksanakan.

Berdasarkan Putusan Mahkamah Agung Nomor 2811/Pid/Sus/2015, yang menjadi permasalahan atau dapat dikategorikan turut serta untuk menjerat si pembuat memo dalam hal ini Drs. Benny Alexander Litelnoni, S.H. M.Si. yang pada waktu itu menjabat sebagai wakil bupati timur tengah selatan dengan membuktikan keterlibatan Drs. Benny Alexander Litelnoni, S.H. M.Si. atau yang membuktikan terpenuhina unsur-unsur tindak pidana yakni:

Bahwa akibat penyaluran dan pembayaran dana bantuan sosial pada Tahun Anggaran 2009 dan 2010 sebagaimana rangkaian perbuatan yang telah dilakukan oleh Terdakwa yang tidak sesuai dengan Pasal 45 ayat (1) dan Pasal 133 ayat (1), (2) Permendagri Nomor 13 Tahun 2006 Tentang Pedoman Pengelolaan Keuangan Daerah yang telah diubah dengan Permendagri No. 59 Tahun 2007 tentang Perubahan Atas Peraturan Menteri Dalam Negeri Nomor 13 Tahun 2006 Tentang Pedoman Pengelolaan Keuangan Daerah dan Keputusan Bupati TTS Nomor PPKAD/5/2009 tanggal 26 Mei 2009 tentang Pemberian Bantuan Sosial Pemerintah Kabupaten Timor Tengah Selatan Tahun Anggaran 2009 dan Keputusan Bupati Nomor 15/KEP/HK/2010 tanggal 21 Januari 2010 tentang Petunjuk Teknis Pemberian Bantuan Sosial Tahun Anggaran 2010 serta Pasal 18 
Ayat (3) Undang-undang Nomor 1 Tahun 2004 Tentang Perbendaharaan Negara yang pokoknya menyatakan "Pejabat yang menandatangani dan/atau mengesahkan dokumen yang berkaitan dengan surat bukti yang menjadi dasar pengeluaran atau beban APBD/APBN bertanggungjawab atas kebenaran material dan akibat yang timbul dari penggunaan surat bukti dimaksud", dapat merugikan keuangan Negara atau Daerah sebesar Rp189.000.000,00 (seratus delapan puluh sembilan juta rupiah) atau setidak tidaknya sejumlah tersebut serta dapat menguntungkan diri sendiri atau orang lain.

Dari fakta/bukti yang ada di persidangan bahwa ada banyak yang membuktikan si pembuat memo Drs. Benny Alexander Litelnoni, SH.MSi, bukan karena memo yang ia keluarkan melainkan ikut terlibat dalam tindak pidan korupsi dana bansos, dimana dalam pencairan dana tersebut banyak daftar penerima dana yang ternyata fiktif atau tidak ditemukan, terdapat pemotongan jumlah dana yang kurang dari seharusnya, terdapat penerima dana bansos yang tidak seharusnya seperti PNS (Pegawai Negeri Sipil), tidak mengikuti mekanisme pencairan dana bantuan sosial seperti yang diatur dalam permendagri dan banyak kasus yang tidak dapat Drs. Benny Alexander Litelnoni, SH.,MSi pertanggungjawabkan dan merugikan keuangan negara bersama Terdakwa Drs. MARTHINUS TAFUI M.Si dan Yakwilina Oematan Alias Yeni.

Perbuatan Terdakwa Drs. MARTHINUS TAFUI, M.Si, bersamasama dengan Yakwilina Oematan Alias Yeni dan Drs. Benny Alexander Litelnoni, SH.Msi (dalam berkas yang terpisah) sebagaimana diatur dan diancam pidana dalam Pasal 3 Jo Pasal 18 Undang-undang Republik Indonesia Nomor 31 Tahun 1999 Tentang Pemberantasan Tindak Pidana Korupsi sebagaimana telah dirubah dengan Undang-undang Republik Indonesia Nomor 20 Tahun 2001 Tentang Perubahan atas Undang-undang Republik Indonesia Nomor 31 Tahun 1999 Tentang Pemberantasan Tindak Pidana Korupsi jo Pasal 55 ayat (1) ke-1 KUHPidana Jo Pasal 64 ayat (1) KUHPidana.

Pasal 3 UU PTPK telah ditentukan cara yang harus ditempuh oleh pelaku tindak pidana korupsi, yaitu

1. Dengan menyalahgunakan kewenangan yang ada pada jabatan atau kedudukan dari pelaku tindak pidana korupsi. Yang dimaksud "kewenangan" adalah hak dan kekuasaan yang dipunyai untuk melakukan sesuatu. ${ }^{11}$

${ }^{11}$ Kamus Besar Bahasa Indonesia, Edisi Ketiga, Balai Pustaka, Jakarta, 2003. hlm. 1272 . 
2. Dengan menyalahgunakan kesempatan yang ada pada jabatan atau kedudukan dari pelaku tindak pidana korupsi. Pada umumnya "kesempatan" ini diperoleh atau didapat sebagai akibat adanya kekosongan atau kelemahan dari ketentuan-ketentuan tentang tata kerja tersebut atay kesengajaan menafsirkan secara salah tehadap ketentuan-ketentuan tersebut.

3. Dengan menyalahgunakan sarana yang ada pada jabatan atau kedudukan dari pelaku tindak pidana korupsi. Yang dimaksud "sarana" adalah syarat, cara, atau media. ${ }^{12}$

\section{KESIMPULAN}

Perbuatan Terdakwa Drs. MARTHINUS TAFUI, M.Si, bersamasama dengan Yakwilina Oematan Alias Yeni dan Drs. Benny Alexander Litelnoni, SH.Msi (dalam berkas yang terpisah) memenuhi unsur-unsur tindak pidana korupsi sebagaimana diatur dan diancam pidana dalam Pasal 3 Jo Pasal 18 Undang-undang Republik Indonesia Nomor 31 Tahun 1999 Tentang Pemberantasan Tindak Pidana Korupsi sebagaimana telah dirubah dengan Undang-undang Republik Indonesia Nomor 20 Tahun 2001 Tentang Perubahan atas Undang-undang Republik Indonesia Nomor 31 Tahun 1999 Tentang Pemberantasan Tindak Pidana Korupsi jo Pasal 55 ayat (1) ke-1 KUHPidana Jo. Pasal 64 ayat (1) KUHPidana.

Apabila Memo yang dikeluarkan oleh Drs. Benny Alexander Litelnoni, SH.Msi selaku wakil Bupati dan Memo tersebut dipedomani oleh bawahannya yang mengakbatkan kerugian negara dan memenuhi unsurunsur Pasal 2 dan Pasal 3 maka Memo tersebut dapat dikualifikasikan sebagai bentuk turut serta.

\section{DAFTAR PUSTAKA}

Amiati, Mia, 2013, Perluasan Penyertaan dalam Tindak Pidana Korupsi Menurut UNCATOC 2000 dan UNCAC 2003. Referensi.

Amiruddin dan Zainal Asikin, 2014, Pengantar Metode Penelitian Hukum. Jakarta: Rajawali Pers

Chazawi, Adami, 2016, Hukum Pidana Korupsi di Indonesia (Edisi Revisi). Jakarta: PT Raja Grafindo Persada.

Hamzah, Andi, 2014, Asas-Asas Hukum Pidana Edisi Revisi. Jakarta: Rineka Cipta.

Idris, Fahmi, 2012, Selamatkan Uang Negara, dengan Tata Kelola Keuangan Negara yang Benar. Jakarta: Expese.

${ }^{12}$ Indroharto, Usaha Memahami Undang-Undang tentang Peradilan Tata Usaha Negara, Buku 1, Pustaka Sinar Harapan, Jakarta, 1993. Hlm.169-171. 
Ilyas, Amir, 2012, Asas-Asas Hukum Pidana. Jakarta: Rangkang Education Yogyakarta \& PuKAP-Indonesia.

Kamus Besar Bahasa Indonesia. 2003. Edisi Ketiga. Jakarta: Balai Pustaka.

Peraturan Menteri Dalam Negeri Nomor 32 Tahun 2011 sebagaimana telah dibah dengan Peraturan Menteri Dalam Negeri Nomor 39 Tahun 2012 tentang Pedoman Pemberian Hibah dan Bantuan yang bersumber dari APBD.

Putusan Mahkamah Konstitusi No. 003/PUU-IV/2006

Reyida, Erika, Korupsi di Indonesia: Masalah dan Solusinya, http://repositry.usu.ac. Diakses Tanggal 14 April 2012. Pukul 18.18 Wita. 